\title{
Psalm 47: Partikularisme en universalisme. Jahwe is ons koning én koning oor die hele aarde
}

W S Prinsloo

\section{ABSTRACT}

Psalm 47: Particularism and universalism. Jahwe is our king and king of all the earth

In this article, Psalm 47 is considered from a text immanent perspective and particular attention is given to the morphological, syntactical, stylistic and semantic facets of the psalm. Although problems of interpretation experienced in respect of Psalm 47 are the same as those for the so-called enthronement psalms, this article concentrates mainly on those research problems that are peculiar to this psalm. Psalm 47 is a hymn comprising of two parallel strophes ( $\mathrm{vv} .2-6$ and 7-10). The reason for the exhortations to praise is the fact that in his deeds of salvation towards Israel, Yahweh has also proved himself to be the mighty, universal king. Psalm 47 probably dates from the exilic or post-exilic period.

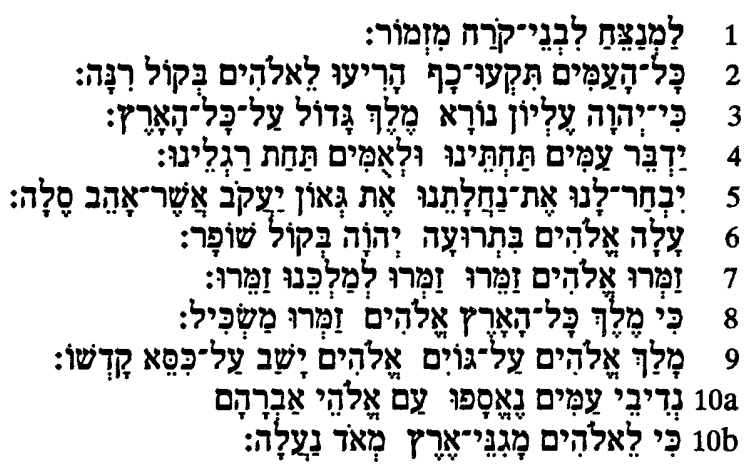

\section{INLEIDEND}

Psalm 47 word gewoonlik saam met Psalm 93, 96, 97, 98 en 99 tot die sogenaamde troonsbestygingspsalms of Jahwe malak-psalms gereken. Psalm 47 deel vanselfsprekend dieselfde navorsingsprobleme as die ander troonsbestygingspsalms ${ }^{1}$ : Dié psalms word gewoonlik òf histories geïnterpreteer en aan 'n spesifieke historiese situasie verbind, of dit word kulties 
geïnterpreteer en aan een of ander kultiese situasie, veral die sogenaamde troonsbestygingsfees, verbind; òf die psalms word eskatologies verklaar. Die betekenis en funksie van die uitdrukking Jahwe malak is ook een van die belangrikste interpretasieprobleme van die bogenoemde psalms.

Psalm 47 dra die opskrif ?ִבְבני־קרָ (letterlik: "vir/van die seuns van Korag”) en word gewoonlik saam met 'n aantal ander psalms, wat dieselfde opskrif het (vgl Pss 42, 44-49, 84-85, 87-88) en dieselfde navorsingsprobleme deel, bestudeer ${ }^{2}$.

In hierdie artikel word egter slegs op die navorsingsprobleme wat eie aan Psalm 47 is, gekonsentreer ${ }^{3}$. Die eerste saak waaroor daar nie eenstemmigheid is nie, is die strofale verdeling. Die mees algemene tendens is om die psalm in twee strofes, naamlik verse $2-6$ en 7-10 te verdeel ${ }^{4}$. Nog 'n tweedeling, maar dan in verse 2-5 en 6-10 kom egter ook voor ${ }^{5}$. Die belangrikste vraag is dus of die skeiding by vers 6 of by vers 7 gesoek moet word. Psalm 47 word egter ook soms in drie ${ }^{6}$ of selfs meer strofes verdeel 7 .

Terwyl daar enersyds 'n opvatting heers dat Psalm 47 'n samehangende geheel en oorspronklike eenheid vorm ${ }^{8}$, is daar andersyds tog ook eksegete wat allerlei redaksionele byvoeginge identifiseer?.

Ook wat die Sitz im Leben - kulties en histories - betref, bestaan daar uiteenlopende gedagterigtings ${ }^{10}$ oor Psalm 47: Die psalm word aan 'n verskeidenheid kultiese geleenthede gekoppel en vanaf die voor-eksiliese tot die ná-eksiliese tyd gedateer. Dikwels word daar meer oor die rekonstruering van die Sitz gespekuleer as wat daar met die teks self geworstel word.

Oor die Gattung van die psalm is daar egter redelike eenstemmigheid, naamlik dat dit as 'n himne beskou moet word.

Hoewel daar hier nie aandag aan die resepsiegeskiedenis van die psalm gegee word nie, moet tog genoem word dat vanaf die vroeë kerk die psalm gebruik is om die hemelvaart van Jesus Christus te vier, 'n gebruik wat vandag soms nog voorkom ${ }^{11}$.

\section{2 'N ANALISE VAN PSALM 47}

By hierdie analise van Psalm 47 word selfs nie eers gepoog om al bogenoemde vrae en probleme te beantwoord nie. Hier word hoofsaaklik op ' $n$ teksimmanente lees van die psalm gekonsentreer. Hierdie benadering pretendeer nie om antwoorde op al die vrae te gee nie, maar sou wel 'n woord kon meespreek wat sommige daarvan betref. Dit is egter ook so dat dit onmoontlik is om op grond van die psalm self antwoorde op sommige van die vrae te kry. 


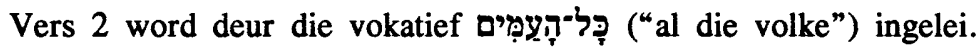
Deur dié uitdrukking voorop in die sinskonstruksie te plaas, word beklemtoon dat dit juis al die nasies is wat opgeroep word tot lof. Die psalm begin daarmee op ' $n$ universele noot. Die nasies/volkere speel

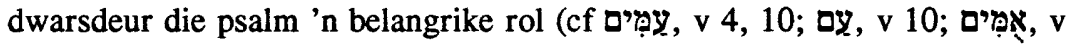

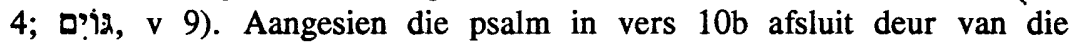
"magtiges" van die volke te praat, kan met Jeremias ${ }^{12}$ saamgestem word dat die "Völkerthema" die psalm van begin tot einde beheers.

Soos wat van 'n himne verwag kan word, word Psalm 47 ook deur imperatiewe tot lof ingelei. Dié element word boonop versterk deurdat

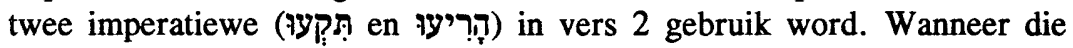
twee vershelftes van vers 2 met mekaar vergelyk word, is dit duidelik dat die twee dele parallel opgebou is en basies uit dieselfde elemente bestaan:

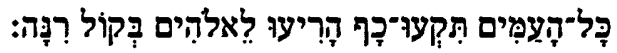

c $\quad d \quad a \quad c \quad a \quad b$

Albei dele bevat element $\mathrm{c}$ (=die manier waarop God geloof moet word) en ook element a (=die werkwoord, imperatiewe); die eerste deel bevat element b (=die subjek van die werkwoorde) terwyl die tweede deel element d (=die objek wat geloof moet word, naamlik Godi3) bevat. Hierdie parallelle opbou en die herhaling van die elemente beklemtoon die feit dat God deur almal en op hoorbare en jubelende wyse geloof moet word.

Vers 3, wat deur 'n motiverende פִ̣ ingelei word, verskaf die rede waarom God geloof moet word en is dus baie nou aan die voorafgaande vers 2 verbind. Die metafoor van Jahwe as koning word hier as motivering gebruik waarom $\mathrm{Hy}$ geloof moet word. Twee nominale sinne word vir dié motivering gebruik:

"Want Jahwe, [die] Allerhoogste [is], gedug/verskriklik

'n groot koning oor die hele aarde".

Hierdie woord wêreld ontleen is, moet hier as 'n himniese attribuut vir Jahwe beskou word waarin $\mathrm{Hy}$ as die hoogste en as die enigste God beskryf word ${ }^{14}$.

Behalwe die motiverende כִ כִ waarna reeds verwys is, word 'n

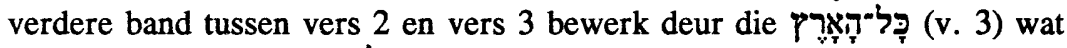

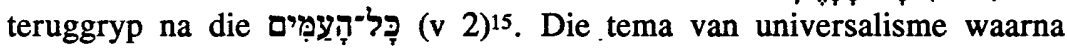
reeds verwys is (cf v 2), word hiermee nog meer versterk. Die uitdrukking

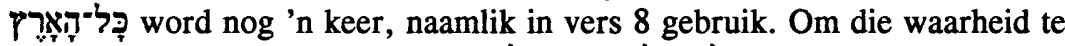

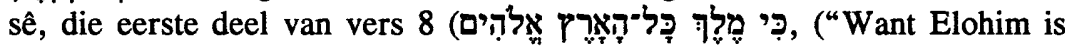
koning oor die hele aarde") stem grootliks ooreen met hierdie tweede deel

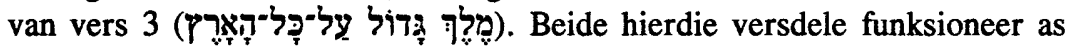


motivering vir die oproep tot lof. Hieruit blyk dat Jahwe se universele koningskap een van dié redes is vir die oproep tot lof.

Nog 'n kenmerk van vers 3 is die alliterasie wat bewerk word deur

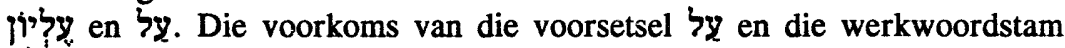
y is egter nie net tot hierdie vers beperk nie. Dit word ook op twee ander plekke in die psalm ten op sigte van Jahwe gebruik. In vers 6 word

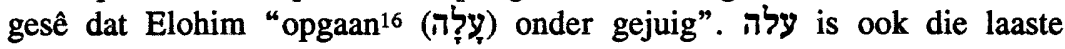
woord in die psalm: "Hy [d i Elohim, W S P] is ten hoogste verhewe"

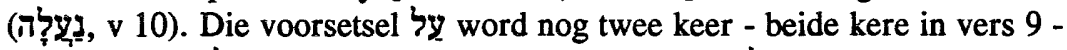

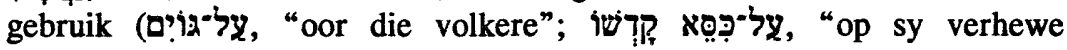
troon"). Uit bogenoemde voorbeelde blyk dit dat die herhaling van die voorsetsel לע en die werkwoordstam yל עלה die gahte van as die verhewe en universele koning sterk beklemtoon ${ }^{17}$.

Vers 4 en 5 stem opvallend met mekaar ooreen deurdat beide verse

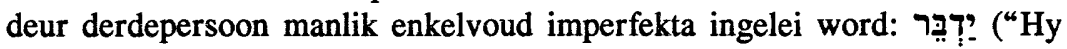

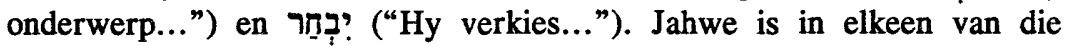
gevalle die subjek van die werkwoord. Daar is nog meer redes waarom hierdie twee verse nou aan mekaar verbind moet word: Die eerstepersoon

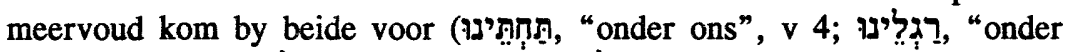

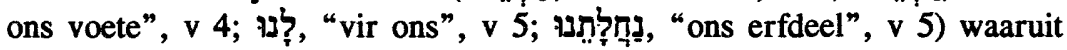
blyk dat die volk van Jahwe hier aan die woord is. Hierdie eerstepersoon enkelvoudvorme bewerkstellig ook klankspel deur middel van die u-klanke. Daar is egter 'n verdere rede waarom vers 4 en 5 nou aan mekaar koppel: Soos aangetoon sal word, word 'n ellips ${ }^{18}$ in beide verse gebruik. Die

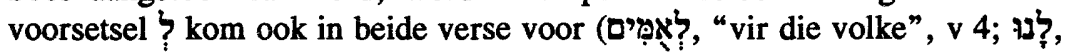
"vir ons", v 5). Soos wat aangetoon sal word, funksioneer die voorsetsel hier kontrasterend. Al hierdie argumente dui daarop dat vers 4 en 5 nou aan mekaar gekoppel is.

Vers 4 en 5 verbind as kombinasie met die voorafgaande vers 3 . Die motiverende partikel ’כִ word by beide verse veronderstel sodat vers 4 en 5 - saam met vers 3 - beskou moet word as motivering vir die oproep tot lof in vers 2 . Vers 4 en 5 is ' $n$ presisering van vers 3 . Vers 4 en 5 spel dus uit wat bedoel word met die stelling dat Jahwe, die Allerhoogste, "gedug" is en dat Hy koning oor die hele aarde is. In vers 4 word dit in "negatiewe" terme gedoen, naamlik dat $\mathrm{Hy}$ die volke aan "ons" (d i Israel) onderwerp het en in 5 word dit in positiewe terme uitgespel in die sin dat Hy "ons" uitverkies het. Hierdeur word 'n kontras tussen Jahwe se strafhandeling teenoor die ander volkere en sy heilshandeling teenoor sy eie volk bewerk. Sowel Jahwe se straf- as sy heilshandelinge funksioneer hier dus as motivering tot lof. Dit is belangrik om daarop te wys dat Jahwe se 
handeling in die geskiedenis in samehang met sy universele koningskap genoem word.

Noudat die verhouding van vers 4 tọt 5 en beide verse se verhouding tot die voorafgaande 3 bepaal is, kan daar individuele aandag aan die verse gegee word. Vers 4 is parallel opgebou en kan soos volg weergegee word:

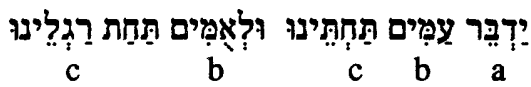

Hieruit blyk duidelik dat element b ("volke"/"nasies") en element c ("onder ons"/"onder ons voete") by beide vershelftes voorkom, maar dat element a (die werkwoord) slegs by die eerste vershelfte voorkom en by die tweede vershelfte veronderstel word sodat ons kan sê dat hier 'n ellips voorkom. Om te kompenseer vir die afwesigheid van element a (die werkwoord) en om die twee vershelftes ook metries te laat balanseer, word

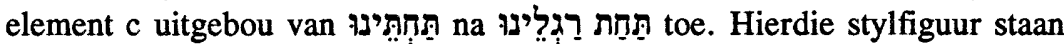
as 'n "ballast variant"19 bekend. Die parallelisme tussen die twee vershelftes word ook verhoog deur die dubbele rym van die im-en die enu-

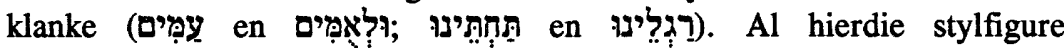
onderstreep dat dit Jahwe self is wat die vreemde volke aan sy eie volk onderwerp het. God word dus hier as krygsman voorgestel, 'n metafoor wat by die koningsmetafoor aansluit. Hier kan op 'n opvallende kontras tussen God en die nasies, bewerk deur die gebruik van voorsetsels, gewys word. Terwyl God hoog en verhewe is (vgl die gebruik van die voorsetsel לy), is die nasies laag, en dus onderworpe (vgl die gebruik van die voorsetsel תחת).

Vers 5 kan soos volg weergegee word:

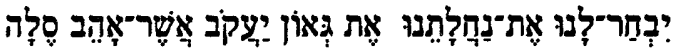 \\ $c$ \\ c $\quad b \quad a$}

Hieruit blyk dat slegs element $\mathrm{c}$ (die objek van die uitverkiesing) by die tweede vershelfte voorkom en dat element a (die werkwoord) en b (לנר, hulle aan wie die heilshandeling/uitverkiesing bewys is) ontbreek. Hier kom daar dus net soos by die vorige versreël 'n ellips voor. Gekombineerd met die ellips kom hier ook - net soos by die vorige versreël - 'n "ballast variant" voor in die sin dat element $\mathrm{c}$ in dịe tweede versreël uitgebou word om te kompenseer vir die afwesigheid van a en b. Sommige eksegete ${ }^{20}$

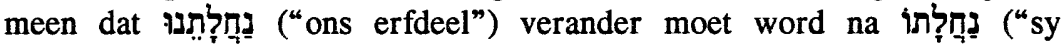
erfdeel") toe. In plaas van "Hy het vir ons ons erfdeel uitgekies", word dus voorgestel "Hy het vir ons as sy erfdeel uitgekies". Behalwe dat daar geen eksterne teksgetuienis vir hierdie voorstel is nie, dui die tweede 


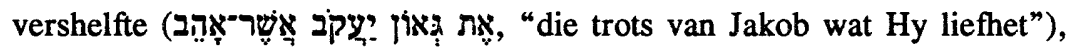
waar die nota accusativus $ת$ ook gebruik word, aan dat die $M T$

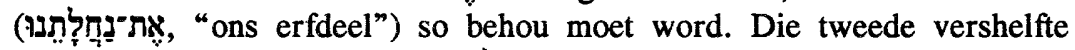

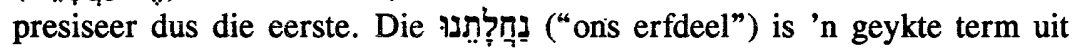
die landsbelofte en -inbesitnametradisie. Die uitdrukking "trots van Jakob", wat dié erfdeel nader omskryf, dui op die erfdeel waarop Israel trots is - die land wat deur Jahwe aan hulle gegee is. Die landsinbesitnametradisie word hier dus as basis vir die koningskap van Jahwe gesien.

Hoewel vers 5 en ook vers 4 na 'n spesifieke geleentheid in die Vergangenheit ${ }^{21}$ verwys, naamlik die onderwerping van die volke van Kanaän en die inbesitname van die land deur God se volk, dui die imperfekta wat in hierdie verse gebruik word tog ook op Jahwe se voortgesette handeling22. 'n Mens sou dus kon sê dat die heilshandelinge van God in die verre verlede nog steeds relevant is vir die digter van Psalm 47 en dat dit steeds 'n rede is waarom God geprys moet word.

Van der Ploeg23 merk op dat vers 6 onverwags opduik. Daar bestaan, soos reeds aangedui, gevolglik nie eenstemmigheid onder eksegete of die vers die afsluiting van die eerste strofe is en of dit die begin van die tweede strofe inlei nie. Daar is selfs 'n opvatting dat vers 6 nie by een van die strofes ingedeel moet word nie, maar 'n oorgang van die een tot die ander strofe vorm ${ }^{24}$.

Wanneer alle faktore in berekening gebring word, kan daar egter tot geen ander gevolgtrekking gekom word as dat vers 6 die afsluiting van die eerste strofe is nie. Eerstens kan genoem word dat God die subjek van die werkwoord verse waar Hy ook die subjek is. Stilisties gesproke, vertoon vers 6 ook dieselfde kenmerke as veral vers 4 en 5 :

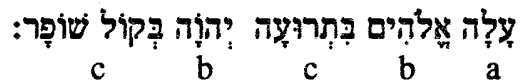

Element a (die werkwoord) kom slegs in die eerste deel van die versreël voor terwyl dit in die tweede versdeel veronderstel word. Met ander woorde, hier word ook 'n ellips gebruik. Vers 6 is egter parallel opgebou wat die ander twee elemente betref. Die twee godsname אֶד staan dus ook hier parallel aan mekaar. In die lig van die waarskynlike polemiese toon van die psalm, kan daar gesê word dat die digter hiermee wou aantoon dat Jahwe wel God is. Hier in vers 6 word ook 'n "ballast variant" aangetref omdat element $c$ in die tweede deel uitgebou word om te kompenseer vir die afwesigheid van element a. Hierdie stylfigure speel, 
soos reeds aangetoon, 'n belangrike rol by verse 3-5. In dié sin sluit vers 6 dus nou by hierdie verse aan. Dit is opmerklik dat vers 6 ook wat woordopname betref nou by die voorafgaande verse aansluit. Om die waarheid te sê, daar sou selfs van 'n inclusio of ringstruktuur gepraat kon word tussen vers 2 en vers 6 omdat daar opvallende woordherhalings

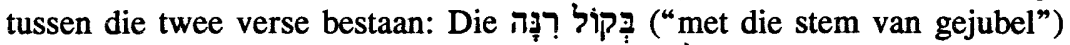

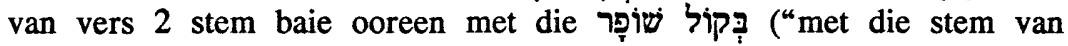

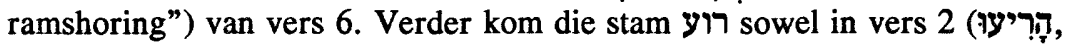

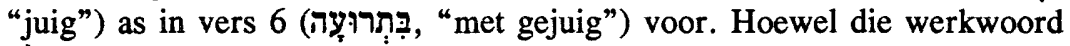
עִ ("Hy gaan op") op verskillende maniere geïnterpreteer kan word25, moet dit hier in terme van die koningsmetafoor verstaan word: God word hier as koning geloof wat sy troon bestyg (vgl ook v 9). Dit beteken egter nie dat ons hier noodwendig met 'n konkrete kultiese situasie te doen het nie.

Daar kan dus met oortuiging gesê word dat vers 6 die afsluiting van die eerste strofe vorm en dat verse 2-6 dus 'n afgeronde strofe vorm.

Die tweede strofe word, soos die eerste strofe ( $\mathrm{vgl} v 2$ ), ingelei deur imperatiewe tot lof. Hierdie imperatiewe bied die eintlike rede waarom gesê kan word dat die tweede strofe nie by vers 6 nie, maar wel by vers 7 begin. 'n Opvallende kenmerk van vers 7 is dat die imperatief İ nie minder as vier keer in hierdie versreël voorkom nie:

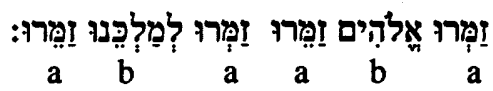

Die twee versdele van vers 7 is parallel opgebou en het soos hierbo aangetoon beide 'n aba-patroon. Hierdie opbou van die versreël laat vanselfsprekend die klem sterk op die feit val dat God geloof moet word. Die himniese element word nog sterker beklemtoon deurdat İ: weer 'n keer, dit wil sê vir die vyfde maal, voorkom ( $v g l ~ v ~ 8)$. Hierdie opbou van

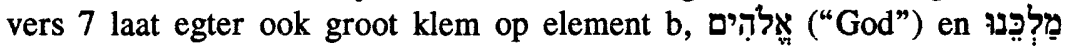
("ons koning") val. Hieruit blyk dat dit veral die koningskap van God is wat geloof moet word. Soos in die geval van die eerste strofe ( $\mathrm{vgl} \mathrm{v} 4$ en 5), word die eerste persoon meervoud ("ons koning") hier gebruik om die persoonlike verhouding tussen God en sy volk tot uiting te laat kom.

Die feit dat Jahwe as koning regeer is, soos reeds aangetoon, die grondliggende motivering vir die oproep tot lof. In vers 3 word Jahwe "'n groot koning" genoem; hier in vers 7 "ons koning"; in vers 8 "koning oor die hele aarde" en in vers 9 word gesê, "Hy heers as koning oor die volke”. 
Die eerste (vv 2-6) en die tweede strofe vertoon sekere parallele met mekaar: Die tweede ( $v$ 7), soos die eerste ( $v$ 2) strofe, word deur imperatiewe ingelei. Die voorsetsel ? word in vers 2 en in vers 7 op soortgelyke wyse gebruik om aan te dui aan wie die lof moet toekom:

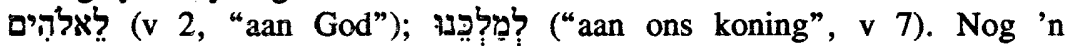
ooreenkoms is dat in hierdie tweede strofe, soos in die eerste strofe, die imperatiewe opgevolg word deur ' $n$ 'כִ waarin die rede vir die imperatiewe tot lof gegee word:

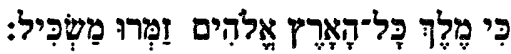

Die motiverende '9 waarmee vers 8 ingelei word, veroorsaak dat vers 8 baie nou aan die voorafgaande vers 7 koppel. Vers 8 gee as motivering vir die oproep tot lof die universele koningskap van God aan. Hierin stem vers 8 opvallend met vers 3 ooreen. Soos vers 3 is vers 8 'n nominale sin. Daar is nog 'n ooreenkoms tussen die eerste en die tweede strofe in die sin dat die nominale $\sin$ waarin '9 voorkom (cf vv 3,8 ) elke keer deur 'n verbale sin opgevolg word (cf vv 4-5, 9)26. Dit blyk ook dat die woord rר 'n sleutelwoord in die psalm is. Hier in vers 8 , soos ook in vers 3 , word dit gebruik om die omvang van God se koningsheerskappy aan te dui

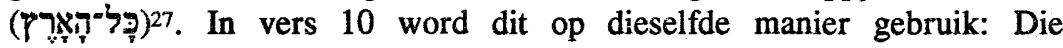

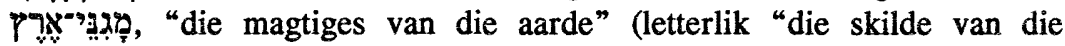
aarde"), behoort aan die Here. Die woord om te sê dat almal, selfs die "magtiges", aan God onderworpe is. Vers 8

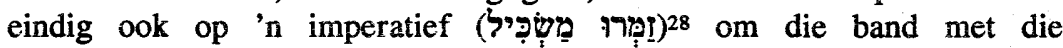
voorafgaande vers nog meer te versterk.

Vers 9 koppel baie sterk aan die voorafgaande vers aangesien dit 'n voortsetting is van die motivering wat deur die by vers 8 ingelei word. Die 'כִ moet dus by vers 9 veronderstel word. Verder is daar ' $n$ anaforiese verhouding tussen dié twee versreëls omdat vers 9 ook deur die stam ingelei word. Inhoudelik sluit vers 9 by 8 aan, want dit gaan vanselfsprekend hier oor die koningskap van God. Die omvang van God se ryk

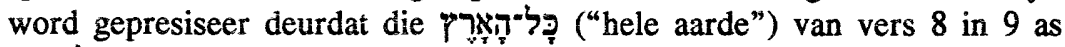

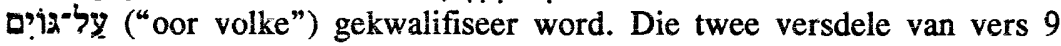
toon parallelle trekke:

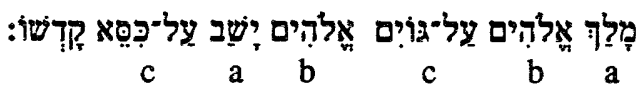

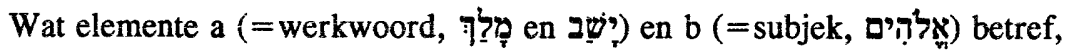
bestaan daar soos wat hierbo blyk 'n chiastiese abba-verhouding tussen die 


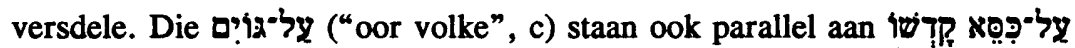

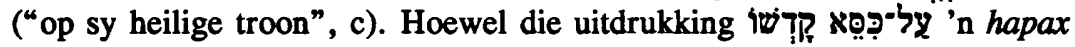
legomenon is in die sin dat dit slegs hier in die Ou Testament voorkom ${ }^{29}$, is die betekenis daarvan tog nie so onduidelik nie - veral as dit binne konteks en in die lig van bogenoemde chiasme gelees word. Die parallelle en chiastiese opbou van die versreël bring die omvang en die aard van God se koningskap na vore. Eerder as om die vers aan een of ander spesifieke kultiese geleentheid te koppel, moet dit gelees word as koningsmetafoor waarmee God se mag beskryf word.

In vers $10 \mathrm{a}$ is God nie meer die subjek nie, maar die vers sluit tog inhoudelik by die voorafgaande aan omdat hier aangetoon word dat die koningskap van God ook op die volkere betrekking het: word nader omskryf as נִּדיבֶי ("edeles/koninklikes van volke"). Daar word soms 'n tekskritiese verandering in vers $10 \mathrm{a}$ voorgestel, naamlik dat ("die volk van die God van Abraham”) verander moet

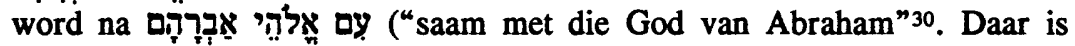
egter ook ' $n$ hele aantal eksegete wat reken dat daar haplografie plaasgevind het wat die en die ay betref en wat gevolglik lees

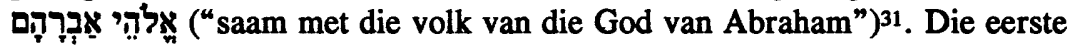
voorstel tot verandering kom daarop neer dat die edeles van die volke saam met die God van Abraham vergader. Die verandering wat van haplografie uitgaan, kom daarop neer dat die leiers van die vreemde volke saam met die volk van die God van Abraham - saam met Israel dus - vergader. Hoewel dié verandering volgens sommige eksegete wel interpretasie probleme sou oplos en waarskynlik 'n makliker tekslesing sou wees, bestaan daar nie eksterne teksgetuienis daarvoor nie en moet die $M T$ liefs behou word ${ }^{32}$. Die $M T$ sê dus dat die leiers van die vreemde volke as die volk van die God van Abraham vergader. Beuken ${ }^{33}$ merk met reg op dat "for the first time in the psalm there is no longer a distinction between 'we' and 'the nations'".

Vers 10a kan soos volg weergegee word:

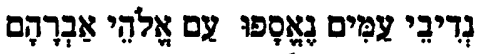
a

b a

Hieruit blyk dat element b (die werkwoord) by die tweede versdeel ontbreek - 'n ellips dus - en dat element a uitgebou word om die hele tweede versdeel op te neem. Hier het ons met 'n "ballast variant" te doen, 'n stylfiguur wat veelvuldig in die psalm voorkom. Element a van die tweede versdeel gee dus 'n verdere verduideliking van element a van die eerste versdeel. In die lig hiervan kan ons sê dat die edeles van die 
vreemde volke hier as 't ware die volk van die God van Abraham word. Dit pas goed in by die strekking van die hele psalm en spesifiek by die direkvoorafgaande vers, naamlik dat God oor al die volke heers. Vers 10a sê dus dieselfde saak net op 'n ander manier.

Dit is belangrik om in hierdie verband op te merk dat termino-logie uit die aartsvadertradisie 'n prominente plek in Psalm 47 inneem. Vers 5 praat van is ("die trots van Jakob") binne die konteks van die uitverkiesende liefde van Jahwe teenoor sy eie volk. Hier in 10a word daar

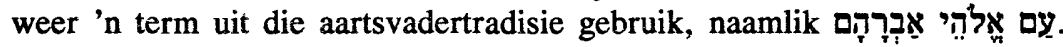
Hier word dit egter nie, soos hierbo aangetoon, van Israel gebruik nie, maar wel van die vreemde volke. 'n Term uit die aartsvadertradisie - ons sou kon sê 'n nasionalistiese of partikularistiese term - word gebruik om die universele heerskappy van Jahwe te verwoord. In vers $10 \mathrm{a}$ vloei partikularisme en universalisme dus ineen. Dit is egter nie 'n nuwe gedagte nie, want vroeër in die psalm is reeds gesê dat Jahwe "ons koning" is (vgl bv v 7) én dat Hy koning oor die "hele aarde" is. Die betekenis van Abraham het veral daarin gelê dat Jahwe hom uit die dampkring van vals gode geroep het tot erkenning van die ware God. Dit is waarskynlik ook die teologiese betekenis van die aartsvadertradisie in hierdie teks ${ }^{34}$.

Vers $10 \mathrm{~b}$ sluit baie nou by die voorafgaande $10 \mathrm{a}$ aan en bevestig dat die "edeles" van die vreemde volke ook as God se volk gereken word. Vers $10 \mathrm{~b}$ moet gesien word as die samevatting van die grondgedagte van die psalm, naamlik dat Jahwe alles beheers. Die 'ִ van 10 is nie motiverend soos dié van vers 3 en 8 nie, maar het 'n bevestigende of

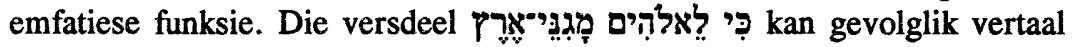
word met "Inderdaad/voorwaar, die skilde van die aarde behoort aan

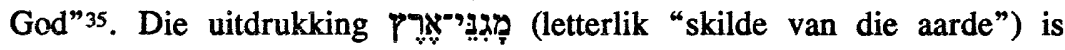
waarskynlik 'n metaforiese manier om van die magtiges van die aarde te praat ${ }^{36}$. Dit is opvallend dat status constructus vorme by sowel 10a (ִּרִיבֶי עצים, "die edeles van die volke") as by $10 \mathrm{~b}$ (die skilde/magtiges van die aarde" ${ }^{37}$ ) voorkom. Hiermee word daar nie net 'n nog nouer band tussen die twee verse gelê nie, maar in die lig van die bespreking tot dusver kan ons sê dat die "edeles" en die "magtiges" dieselfde groep mense aandui. In sowel vers $10 \mathrm{a}$ as $10 \mathrm{~b}$ gaan dit oor die erkenning deur die volke van Jahwe se universele koningskap.

Vers $10 \mathrm{~b}$, en dus die psalm as geheel, eindig letterlik op 'n

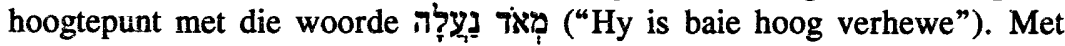
hierdie uitdrukking gryp vers $10 \mathrm{~b}$ weer terug na vers 2 en na vers 6 toe en kan daar met reg gesê word dat die verhewenheid van Jahwe as koning die hooftema van die psalm en die hoofrede tot die oproep tot lof is. Dat God 
"verhewe" is beteken dat Hy alle mag in die hande het - dat Hy koning is.

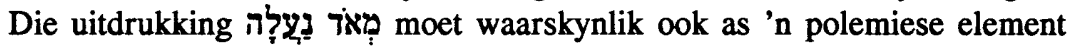
beskou word.

Die psalm as geheel vorm ook 'n inclusio deurdat die uitdrukking לִאלרים ("vir/aan God") sowel aan die begin (vgl v 2) as aan die einde (vgl 10b) voorkom. Dit moet ook nog vermeld word dat die woord ארֵ

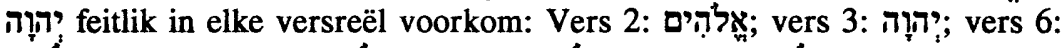

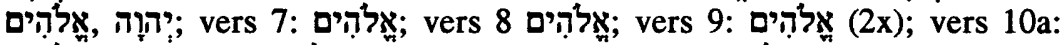

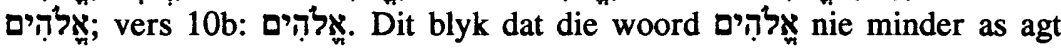
maal in die psalm voorkom nie. Selfs in vers 4 en 5 waar dit nie voorkom nie, is God die subjek van die werkwoorde. Hieruit kan afgelei word dat Psalm 47 in die volle sin van die woord ' $n$ teosentriese psalm is en dat alle lof Hom toekom. Zenger ${ }^{38}$ toon aan dat daar in die eerste strofe (vv. 2-6) 'n oproep is om God se lof te akklameer, terwyl dit in die tweede strofe (710) meer om 'n oproep tot proklamasie of verkondiging van God se koningskap gaan.

\section{KONKLUSIE}

Op grond van die voorafgaande analise van die psalm kan die volgende samevattende opmerkings gemaak word:

Psalm 47 bestaan uit twee strofes, naamlik verse 2-6 en 7-10. Die strofes het 'n parallelle opbou in die sin dat beide strofes bestaan uit oproepe tot lof wat gevolg word deur motiveringe waarom Jahwe geloof moet word. Die basiese rede vir die oproepe tot lof is die feit dat Jahwe die verhewe, magtige en universele koning is. Jahwe het homself as magtige koning bewys op grond van sy heilsdade in die geskiedenis.

Van Uchelen ${ }^{39}$ vat die inhoud en bedoeling van die psalm dus met reg soos volg saam: "Gods koningschap is verworteld in zijn handelen aan Israël en zal vrucht dragen in zijn verhouding tot de volken”. Die verskil tussen Israel en die volke word opgehef in Psalm 47. Die volke en hulle leiers kom tot die erkenning dat Jahwe oor almal en alles regeer. Partikularisme en universalisme vloei dus ineen.

Oor die historiese en kultiese Sitz kan die volgende opmerkings gemaak word. Dit kan nie ontken word dat Psalm 47 terminologie uit die voor-eksiliese kultus en terminologie uit die troonsbestyging van 'n aardse koning en selfs motiewe uit die kanaänitiese wêreld gebruik het nie. Ten spyte van dié terminologie is dit tog nie moontlik om die psalm op grond van sy eie inhoud aan 'n spesifieke kultiese of historiese situasie te verbind nie $^{40}$. 'n Mens moet ook aanvaar dat die psalm afgesien van sy 
oorspronklike situasie telkens in ander kultiese of liturgiese situasies gefunksioneer het.

Indien ek egter 'n keuse oor die ontstaandatum sou moes maak, sou ek kies vir die eksilies/na-eksiliese tyd. 'n Paar sake wys in hierdie rigting. Ten spyte van die feit dat die psalm teruggryp op en gebruikmaak van voor-eksiliese motiewe en terminologie is daar tog tekens van stilistiese en teologiese ooreenkomste met 'n boek soos Deuterojesaja sodat gesê kan word dat die psalm ten minste in die ballingskap kon ontstaan het ${ }^{41}$. Die klem op die universalistiese koningskap van Jahwe sou kon dui op 'n tyd toe die Judese monargie nie meer bestaan het nie. Die psalm wil deur sy optimistiese wêreldbeskouing sê dat Israel nieteenstaande, of juis te midde van, die ballingskap geglo het dat God koning is. Die funksie van hierdie himniese psalm sou dus wees om mense op te roep tot lof, maar tog ook om hulle te vertroos en moed te gee. Die polemiese aard van die psalm waarna telkens verwys is, sou in beide hierdie elemente se diens kon staan.

Terwyl hierdie uitgawe van Skrif en Kerk op die eenheid van die kerk en op die verhouding tussen eenheid en verskeidenheid konsentreer, kan in dié verband vermeld word dat Zenger ${ }^{42}$ met reg opmerk dat Psalm 47 die volke tot eenheid in 'n versoende verskeidenheid oproep. Eenheid en verskeidenheid - of om dit anders te stel, universalisme en partikularisme word dus met mekaar versoen in Psalm 47. Eenheid, volgens Psalm 47, bestaan in die erkenning van Jahwe as koning.

\section{NOTAS:}

1 Aangesien ek elders meer volledig oor dié problematiek geskryf het, word die probleme nie hier weer bespreek nie. Vergelyk W S Prinsloo, "Psalm 93: Jahwe is van altyd af Koning oor alles en almal”, NGTT 34/3 (1993), 248-261; W S Prinsloo, "Psalm 99: Die Here, ons God is heilig", HTS 49/3 (1993), 621-636; W S Prinsloo, "Psalm 98: Sing 'n nuwe lied tot lof van die Koning, Jahwe", HTS 50/1 \& 2 (1994), 155-168; W S Prinsloo, "Psalm 97: Almal moet bly wees, want Jahwe is Koning”, HTS 51/4 (1995), 1088-1113; W S Prinsloo, "Psalm 95: If only you will listen to his voice!", in: M D Carroll, D J A Clines \& P R Davies, The Bible in human society. Essays in honour of John Rogerson (JSOT SS 200), Sheffield 1995, 393-410.

2 Hier word ook nie ingegaan op die problematiek (byvoorbeeld die samehang, redaksiegeskiedenis en historiese en kultiese Sitz im Leben) van die Koragpsalms nie. Vergelyk hiervoor byvoorbeeld G Wanke, Die Zionstheologie der Korachiten (BZAW 97), Berlin 1966; M D Goulder, The Psalms of the sons of Korah (JSOT SS 20), Sheffield 1982; E Zenger, "Zur redaktionsgeschichtlichen Bedeutung der Korachpsalmen", in: K Seybold \& E Zenger (Hrg), Neue Wege der Psalmenforschung (Herders Biblische Studien 1), Freiburg/Basel/Wien 1994, 175-198. 
3 Vergelyk $\mathrm{O}$ Loretz, Ugarit-Texte und Thronbesteigungspsalmen. Die Metamorphose des Regenspenders Baal-Jahwe (Ps 24, 7-10; 29; 47; 93; 95-100 sowie Ps 77, 17-20; 114), Münster 1988, 41-51 vir 'n volledige Forschungsgeschichte van Psalm 47. Vergelyk ook A Caquot, "Le psaume 47 et la royauté de Yahwé", Revue D'Histoire et de Philosophie Religieuses 39/4 (1959), 312-314.

4 Vergelyk byvoorbeeld H Hupfeld/W Nowack, Die Psalmen I, Gotha 31888 , 644; H Gunkel, Die Psalmen, Göttingen 61986, 202; J Muilenburg, "Psalm 47", JBL 63 (1944), 246; E J Kissane, The book of Psalms I, Dublin 1953, 205207; H-J Kraus, Psalmen 1.Teilband (BKAT XV/1), Neukirchen-Vluyn ${ }^{3} 1966$, 350-354; J P M van der Ploeg, Psalmen I (BOT), Roermond 1973, 287, 291; L G Perdue, "Yahweh is king over all the earth'. An exegesis of Psalm 47", Restoration Quarterly 17 (1974), 91; N A van Uchelen, Psalmen deel II (POT), Nijkerk 1977, 48-52; P C Craigie, Psalms 1-50 (WBC), Waco 21984, 347; J Jeremias, Das Königtum Gottes in den Psalmen. Israels Begegnung mit den kanaanäischen Mythos in den Jahwe-König-Psalmen (FRLANT 141), Göttingen 1987, 51; E S Gerstenberger, Psalms Part I with an Introduction to cultic poetry, Grand Rapids, Michigan 1988, 196; F-L Hossfeld \& E Zenger, Psalmen $I$ (NEB 29), Würzburg 1993, 290-291; J L Mays, Psalms (Interpretation), Louisville 1994, 186. Hoewel W G E.Watson, Classical Hebrew poetry. A guide to its techniques (JSOT SS 26), Sheffield 21986, die psalm in 5 stansas, naamlik 2-3, 4-5, 6, 7-8, en 9-10 verdeel, kom sy verdeling basies ook op 'n tweeledige $2-6$ en $7-10$ verdeling neer.

5 Vergelyk byvoorbeeld H Schmidt, Die Psalmen (HAT 15), Tübingen 1934, 90; A A Anderson, Psalms (1-72) (NCBC), Grand Rapids, Michigan 21981, 360; J Ridderbos, De Psalmen (COT), Kampen 1958, 54-58; B Janowski, "Das Königtum Gottes in den Psalmen”, ZThK 86 (1989), 438-439; J S Sibinga, "Some observations on the composition of Psalm XLVII", VT 38 (1988), 474479 kom op grond van 'n woordtelling tot 'n 2-5, 6-10 verdeling. Hy bespeur allerlei konsentriese patrone in beide strofes asook 'n "mathemetical centre" van die psalm. Om bloot op grond van 'n woordtelling tot sulke konklusies te kom, oortuig egter nie.

$6 \quad \mathrm{P}$ van der Lugt, Strofische structuren in de Bijbels-Hebreeuse poezie, Kampen 1980,262 , verdeel die psalm in drie stansas, naamlik verse 2-5, 6-9 en 10. Dié indeling is reeds vroeër die eeu deur H Herkenne, Das Buch der Psalmen (Die Heilige Schrift des AT V/2), Bonn 1936, 177-179 gemaak. R Kittel, Die Psalmen (KAT XIII), Leipzig/Erlangen ${ }^{41922,174-179}$ en A F Kirkpatrick, The book of Psalms, Cambridge 121957, 259 neem verse 2-5, 6-8 en 9-10 as indeling.

7 Vergelyk Van der Lugt, $a w, 263-264$ vir 'n oorsig oor die belangrikste eksegete se strofale verdelings. C A \& E G Briggs, The book of Psalms vol I (ICC), Edinburgh ${ }^{4} 1927$, verdeel die psalm in vyf strofes, naamlik verse 2-3, 4- 
5, 6-7, 8-9 en 10; D Michel, Tempora und Satzstellung in den Psalmen, Bonn 1960, 218 verdeel die Psalm in vier dele, naamlik verse 2-5, 6, 7-8 en 9-10.

J Schaper, “Psalm 47 und sein 'Sitz im Leben'”, ZAW 106 (1994), 263, stel dit soos volg: "Wir gehen also im folgenden von der literarischen Einheitlichkeit von Ps 47,2-10 aus".

$9 \quad$ Vergelyk byvoorbeeld Briggs \& Briggs, $a w, 398$. Loretz, $a w, 64$ voer op grond van sy kolometriese analise aan dat slegs verse 2, 6 en 9 tot die kern van die psalm behoort. Die res van die psalm, verse 3-5, 7-8 en 10, sê hy, is deel van 'n latere redaksiefase. E Zenger, "Der Gott Abrahams und die Völker. Beobachtungen zu Psalm 47”, in: M Görg (Hrsg), Die Väter Israels. Beiträge zur Theologie der Patriarchenüberlieferungen im Alten Testament, Stuttgart 1989, 425 kom na 'n literêr-kritiese analise tot die gevolgtrekking dat slegs verse 2-3a, 6-8a en 9 tot die "Grundschicht" van die psalm hoort. Die res van die psalm is na die tyd bygevoeg.

10 Vergelyk Loretz, $a w, 50$ voetnoot 33 waarin hy aantoon en voorbeelde gee van die feit dat die psalm deur eksegete vanaf die intog in die land tot in die naeksiliese tyd gedateer word. Loretz, $a w, 65$ self is van mening dat een deel van die psalm (vv 2, 6 en 9) uit die voor-eksiliese tyd kom, terwyl die res van die psalm (vv 3-5, 7-8 en 10) uit die na-eksiliese Joodse gemeente afkomstig is. Vergelyk ook Zenger, $a w, 1989,425-426$ wat die een deel van die psalm in die agste eeu dateer, terwyl die latere bewerking van die psalm volgens hom uit die eksiliese of selfs na-eksiliese tyd kom.

K H Ratschow, “Epikrise zum Psalm 47", ZAW 53 (1935) verbind Psalm 47 byvoorbeeld aan wat hy noem die Königskult. In dié ritueel word die koning as 'n kultuspersoon as 't ware God én wêreldheerser. Ratschow maak dié gevolgtrekkings veral op grond van Egiptiese en Assiriese parallelle. J M Roberts, "The religio-political setting of Psalm 47", BASOR 221 (1976), 132, probeer 'n kultiese en historiese raamwerk vir die psalm skep en verwoord dit soos volg: "This observation suggest a setting for the psalm in a cultic celebration of Yahweh's imperial accession, based on the relatively recent victories of David's age, which raised Israel from provincial obscurity to an empire of the first rank".

Kirkpatrick, $a w, 259$ plaas die psalm ook in die voor-eksiliese tyd, naamlik die agste eeu; vergelyk ook byvoorbeeld Ridderbos, $a w, 50$; Kissane, $a w, 205$; Goulder, $a w, 157$; Muilenburg, $a w, 250$; Jeremias, $a w, 68$ wat almal die psalm voor-eksilies dateer.

Briggs \& Briggs, a $w, 398$ dateer die psalm na-eksilies, naamlik in die Persiese periode. J Ohlshausen, Die Psalmen,- Leipzig 1853, 207 dink aan die Makkabese tyd as ontstaansdatum.

B Duhm, Die Psalmen (KHAT XIV), Tübingen 21922, 195 is van mening dat ons hier met 'n liturgiese komposisie te doen het sodat "über seine Abfassungszeit kaum etwas näheres auszumachen ist". 
11 Ridderbos, $a w, 58$ maak in dié verband die volgende opmerking oor vers 10: "Ook hier ligt weer, evenals in vs 6 en vs 9, de gedachte aan Christus' hemelvaart zeer voor de hand'.

12 Jeremias, $a w, 52$.

13 W A M Beuken, "Psalm XLVII: Structure and drama", in: A S Van der Woude, Remembering all the way... (OTS XXI), Leiden 1981 40, wys met reg daarop dat die ? by לאל ? as 'n "double-duty prefix" funksioneer en dat

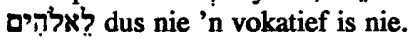

14 Schaper, $a w, 266$.

15 Van der Lugt, a w, 263 wys daarop dat die twee uitdrukkings in 'n chiastiese relasie staan.

16 Die Afrikaanse Bybelvertaling (1983), "God gaan op na sy tempel toe...", voer die beginsel van die dinamies-ekwivalente vertalingswyse hier te ver. Die opvatting van die vertalers is op die teks afforseer, want hier is geen sprake van "tempel" in die teks nie.

17 Watson, $a w, 373$ merk dus met reg op: "The twin repetition of iby (middle and end of poem) reinforces the divine title preposition y (x3)".

18 Hier word angesluit by die definisie wat Watson, $a w, 303-304$, van ellips gee: "Ellipsis is the omission of a particle, word or group of words within a poetic or grammatical unit, where its presence is expected".

19 Watson, $a w, 344$ omskryf dié stylfiguur soos volg: “...a ballast variant is simply a filler, its function being to fill out a line of poetry that would otherwise be too short”. Vergelyk ook W Bühlmann \& K Scherer, Stilfiguren der Bibel. Ein kleines Nachschlagewerk, Fribourg 1973, 36.

20 Vergelyk die tekskritiese apparaat van $B H S$ waar aangetoon word dat die $L X X$ en die Siriese vertaling vir die moontlikheid kies. Vergelyk ook Roberts, $a w$, 130.

21 Vergelyk Hossfeld \& Zenger, $a w, 1993,292$.

22 Goulder, $a w, 115$, formuleer dit met reg soos volg: "The imperfects ... stand for the continuity of the divine action".

$23 A$ A, 292: "Dit vers komt onverwacht, onvoorbereid". Olshausen, $a w, 206$ het ook reeds in die vorige eeu opgemerk dat vers 6 geïsoleerd is.

24 Vergelyk Schaper, $a w, 264-265$ in hierdie verband. 
25 Die werkwoord verwys volgens sommige eksegete na God se opvaart na die hemel toe (hemel hier in die Ou-Testamentiese sin van die woord, vgl Gen 17:22; 35:13; Rig 13:20). Dit sou kon dui op die ark - as simbool van die teenwoordigheid van Jahwe - wat in prossessie na die tempel toe gedra is (vgl 2 Sam 6:5). S Mowinckel, The Psalms in Israel's worship I, Oxford 1962, 171 verteenwoordig dié standpunt, wat binne konteks van sy troonsbestygingshipotese verstaan moet word: "The royal entry of Yahweh, at which he himself is present, symbolized by his holy 'ark', is the pre-eminent visible centre of the experiences connected with the enthronement festival". Vergelyk ook Jeremias, $a w, 58$ wat dit ook met die ark verbind. Hossfeld \& Zenger, $a$ w, 1993, 292 sê dat word en dat dit as "Inbesitznahme des Zion als Thronsitz" gelees moet word. Hossfeld \& Zenger, ibid, sê verder ook dat dit moeilik is om die spesifieke kultiese geleentheid te bepaal en dat die Ladeprozession wat deur meeste geleerdes aanvaar word nie bewys kan word nie. Vergelyk verder Loretz, $a w$, 57-58 wat 'n uitvoerige uiteensetting gee van die verskillende maniere waarop 旅 in die loop van die tyd geïnterpreteer is.

26 Vergelyk Beuken, $a w, 41$.

27 M Dahood, The Psalms I (AB 16), Garden City, New York 41966, wys daarop dat die uitdrukking 'n polemiese toon het. Ek is ook van mening dat die sogenaamde troonsbestygingspsalms $(47,93,96-99)$ talle polemiese elemente bevat. Die saak sou egter 'n volledige ondersoek vereis.

28 Hoewel die betekenis van die woord die betekenis van 'n loflied (vgl Craigie, $a w, 349$ ).

29 Van der Ploeg, a w, 293.

30 Vergelyk byvoorbeeld die $L X X$.

31 Byvoorbeeld Gunkel, $a w, 201$; Duhm, $a w, 194$; Briggs \& Briggs, $a w, 400$; Kirkpatrick, $a w, 262$; Craigie, $a w, 347$; Van der Ploeg, $a w, 287$; Kraus, $a w$, 348; M Buttenwieser, The Psalms, Chicago/lllinois 1938, 353; W O E Oesterley, The Psalms I, London 1939, 259; F Nötscher, Die Psalmen (ATD), Würzburg 41953, 94; A Deissler, Die Psalmen, Düsseldorf 21979, 192.

32 Muilenburg, $a w, 243$ merk met reg op: "To alter the text in a way that is stylistically awkward, without strong manuscript support... and in a way that is contrary to the movement of the poem as a whole, is to distort the obvious purport of the poem". Onder diegene wat ook die $M T$ behou, tel byvoorbeeld: H Schmidt, $a w, 190$; Kittel, $a w, 171$; König, $a w, 224$; Van der Lugt, $a w$, 262; A Weiser, Die Psalmen I (ATD 14/1), Göttingen 41955, 252; Hossfeld \& Zenger, $a w, 1993,291$; Schaper, $a w, 262$. 
$33 \quad A w, 47$.

$34 \quad$ Zenger, $a w, 1989,429$.

35 Vergelyk Herkenne, $a w, 179$.

36 Hupfeld/Nowack, $a w, 647$.

37 O Loretz, "Psalmenstudien III", Ugarit-Forschungen 6 (1974), 179, vertaal die uitdrukking מגבי־ארץ "geskenke van die aarde". Om by dié interpretasie uit te kom, moet hy egter die laaste deel van vers $10 \mathrm{a}$ as latere redaksionele byvoeging beskou.

$38 \quad$ Zenger, $a w, 1989,425$.

39 Van Uchelen, $a w, 49$.

40 Beuken, $a w, 39$.

41 Vergelyk Schaper, $a w, 269-273$, vir 'n motivering van dié stelling.

42 Zenger, $a w, 1989,430$. 